\title{
Ćwiczenia kompleksowe na lotnisku jako element doskonalenia zawodowego strażaków Państwowej Straży Pożarnej
}

\section{Comprehensive (full-scale) exercises at the airport as element of the professional development of firefighters of the State Fire Service}

\begin{abstract}
Streszczenie:
Niniejszy artykuł stanowi próbę analizy postrzegania tematyki ratownictwa lotniskowego przez pryzmat zadań wykonywanych przez strażaków Państwowej Straży Pożarnej, czyli pomocniczej służby zewnętrznej. Autor artykułu prowadzi rozważania na podstawie przeprowadzonych wcześniej przez niego badań na temat przydatności w procesie doskonalenia zawodowego udziału strażaków Państwowej Straży Pożarnej w ćwiczeniach kompleksowych na lotnisku.
\end{abstract}

Słowa kluczowe: ćwiczenia kompleksowe na lotnisku, ratownictwo lotniskowe, doskonalenie zawodowe PSP, Państwowa Straż Pożarna

\begin{abstract}
:
This article is an attempt to analyze the perception of the subject of airport rescue through the prism of tasks performed by the State Fire Service firefighters, i.e. an auxiliary external service. The reflections of the author are based on his earlier research on the usefulness of the participation of State Fire Service firefighters in comprehensive (full-scale) exercises at the airport in the process of professional development. Keywords: comprehensive (full-scale) exercises at the airport, airport rescue, professional training of the State Fire Brigade, State Fire Brigade
\end{abstract}


Artur Musiał - Ćwiczenia kompleksowe na lotnisku...

\section{Wprowadzenie}

Na mocy art. 5 ustawy zasadniczej organy państwa odgrywają z instytucjonalnego punktu widzenia główną rolę w zapewnieniu bezpieczeństwa obywateli ${ }^{1}$. Lotnisko jest miejscem szczególnym, na którym zagadnieniami bezpieczeństwa zajmują się zarówno podmioty państwowe, jak i pozapaństwowe. W komunikacji lotniczej kwestię bezpieczeństwa należy rozpatrywać pod kątem operacyjnym (safety), w rozumieniu bezpiecznego wykonywania lotów, jak również w sensie ochrony i przeciwdziałania zagrożeniom terrorystycznym lub aktom bezprawnej ingerencji ${ }^{2}$ (security). Obowiązujące przepisy czynią podmiot zarządzający lotniskiem³ ${ }^{3}$ a więc pozapaństwowy, odpowiedzialnym za bezpieczeństwo zarówno w rozumieniu safety, jak i security. Naczelnym krajowym aktem prawnym regulującym tenże obowiązek jest Ustawa z dnia 3 lipca 2002 r. - Prawo lotnicze, jednakże unormowania obszarów bezpieczeństwa i odpowiedzialności za nie zarządzającego zawarte są również w przepisach międzynarodowych i unijnych.

W dniu 7 grudnia 1944 r. w Chicago została podpisana Konwencja o międzynarodowym lotnictwie cywilnym ${ }^{4}$ (potocznie - konwencja chicagowska). Treść konwencji w postaci umowy międzynarodowej regulującej zakres prawa lotniczego oraz na jej podstawie przyjęte wówczas 18 załączników ${ }^{5}$ uznawane są za główne źródło międzynarodowego prawa lotniczego. Jej najważniejszym zapisem jest powołanie Organizacji Międzynarodowego Lotnictwa Cywilnego (ang. Internatio-

\footnotetext{
${ }^{1}$ Konstytucja Rzeczypospolitej Polskiej z dnia 2 kwietnia 1997 r. (Dz.U. 1997, Nr 78, poz. 483).

2 A. K. Siadkowski, Prawodawstwo w ochronie lotnictwa cywilnego, Dąbrowa Górnicza 2015, s. 9.

${ }^{3}$ Podmiot, który został wpisany jako zarządzający do rejestru lotnisk cywilnych art. 2 ust. 7. ustawy z dnia 3 lipca 2002 r. - Prawo lotnicze (t.j. Dz.U. 2002, Nr 130, poz. 1112).

4 Polska ratyfikowała Konwencję w 1958 r. (Dz.U. 1959, Nr 35, poz. 212 ze zm.).

514 listopada 2013 r. wszedł w życie Załącznik 19 - Zarządzanie bezpieczeństwem, http://www.ulc.gov.pl/pl/prawo/prawo-mi\%C4\%99dzynarodowe/206-konwencje [dostęp;12-04-2019].
} 
nal Civil Aviation Organization, ICA0) ${ }^{6}$. Ułatwianie międzynarodowej żeglugi powietrznej oraz ciągłe dążenie do poprawy jej efektywności i bezpieczeństwa, poprzez m.in. stosowanie się do międzynarodowych norm i zaleceń w kwestii bezpieczeństwa (jest tam także odniesienie do organizacji ćwiczeń na lotnisku) ustanowionych przez ICAO, jest jednym z podstawowych obowiązków państw członkowskich organizacji. Dla bezpieczeństwa lotnisk kluczowym załącznikiem jest załącznik 14 i wydane do niego podręczniki.

W Europie z chwilą utworzenia Agencji Unii Europejskiej d.s. bezpieczeństwa lotniczego (ang. European Union Aviation Safety Agency EASA) w roku 2002 bezpieczeństwo w znaczeniu safety ujęto w nowe ramy instytucjonalne. EASA przejęła od państw członkowskich Unii Europejskiej (UE) zadania w obszarze bezpieczeństwa lotniczego. Swą działalność rozpoczęła w 2003 r. i na jest dzisiaj obok Komisji Europejskiej, organizacji EUROCONTROL oraz krajowych władz lotniczych najważniejszym filarem UE w zakresie bezpieczeństwa operacyjnego (safety). EASA opracowuje specyfikacje certyfikacyjne (Certification Specifications - CS) i materiały zawierające wytyczne (Guidance Material GM) ${ }^{7}$. Stanowią one instrument interpretacyjny dla przepisów technicznych i nie mają charakteru prawa powszechnie obowiązującego. W całości regulacji prawa unijnego EASA, a wraz za nią Parlament Europejski i Rada, wprowadzają odwołania do regulacji międzynarodowych ustanawianych przez ICAO. Polityka ta uwidacznia dążenie do ujednolicania przepisów, co ma na celu utrzymanie jednolitego poziomu bezpieczeństwa $w$ transporcie lotniczym ${ }^{8}$.

Ustawa Prawo lotnicze w art. 84 nakłada na zarządzającego konieczność zapewnienia ochrony przeciwpożarowej lotniska, a w tym także znajdujących się na jego terenie obiektów budowlanych. Wymaganie to realizowane jest poprzez opracowanie planu działania w sytu-

\footnotetext{
${ }^{6}$ J. Szczucki, M. Gąsior, G. Zając, M. Szczelina Zarzq̨dzanie bezpieczeństwem lotnictwa cywilnego. Skrypt dydaktyczny, Wrocław 2011, s. 113.

7 K. Łuczak (red.), Zarządzanie bezpieczeństwem $w$ lotnictwie cywilnym, Katowice 2016, s. 133.

8 Ibidem, s. 135.
} 
Artur Musiał - Ćwiczenia kompleksowe na lotnisku...

acji zagrożenia i uzgodnienie go z właściwym terenowo komendantem wojewódzkim Państwowej Straży Pożarnej oraz organizację i zapewnienie funkcjonowania służby ratowniczo-gaśniczej (Lotniskowej Służby Ratowniczo-Gaśniczej - LSR-G) wyposażonej w specjalistyczny sprzęt. Widać zatem, że działania te mieszczą się w obszarze safety. Planowanie działań w sytuacji zagrożenia wymaga uwzględnienia w tym procesie służb zewnętrznych. Jedną z nich, dla której przewidziane są - z uwzględnieniem jej statutowych zadań - działania ratowniczogaśnicze, jest Państwowa Straż Pożarna9 ${ }^{9}$ (PSP). Mimo że PSP jest służbą państwową, stanowi niezbędny substytut dla LSR-G podczas działań w sytuacji zagrożenia na terenie portu lotniczego, dlatego też znajomość i umiejętność stosowania taktyk ratowniczych oraz koordynacja współpracy obu formacji staje się rzeczą ogromnie ważną dla skutecznego prowadzenia działań ratowniczo-gaśniczych czy to podczas realizacji ratownictwa lotniskowego po wypadku statku powietrznego, czy też innych zagrożeń mogących wystąpić na lotnisku, nie związanych z udziałem statku powietrznego.

$\mathrm{Na}$ potrzeby niniejszego artykułu zamiennie zastosowano użycie nazw: lotnisko (domyślnie lotnisko użytku publicznego ${ }^{10}$ ) i port lotniczy11. Pojęcia: lotnisko i port lotniczy są ze sobą powiązane i współzależne - jednak w ogólnym znaczeniu różnią się od siebie. Ujmując oba terminy w najprostsze ramy, stwierdzić należy, że pojęciu lotnisko bliżej jest do zagadnień operacyjnych, natomiast port lotniczy kieruje się w stronę działalności gospodarczej (handlowej). Biorąc jednak pod uwagę temat rozważań poruszany w niniejszym artykule, przyjąć moż-

${ }^{9}$ Państwowa Straż Pożarna jest zawodową, umundurowaną i wyposażoną w specjalistyczny sprzęt formację, przeznaczoną do walki z pożarami, klęskami żywiołowymi i innymi miejscowymi zagrożeniami - art. 1 ust. 1 ustawy z dnia 24 sierpnia $1991 \mathrm{r}$. o Państwowej Straży Pożarnej (t.j. Dz.U. 1991, Nr 88, poz. 400).

10 Lotnisko otwarte dla wszystkich statków powietrznych w terminach i godzinach ustalonych przez zarządzającego tym lotniskiem i podanych do publicznej wiadomości - art. 54 ust. 2 ustawy Prawo lotnicze

11 Port lotniczy jest to lotnisko użytku publicznego wykorzystywane do lotów handlowych - art. 2 ust. 17 ustawy Prawo lotnicze. 
na, że oba pojęcia są tożsame i można je stosować zamiennie. Interpretację taką przyjął właśnie autor artykułu.

Niniejszy artykuł stanowi próbę analizy postrzegania tematyki ratownictwa lotniskowego przez pryzmat zadań wykonywanych przez strażaków Państwowej Straży Pożarnej, czyli służby zewnętrznej w tym jednym z nielicznych przypadków pomocniczej. Zagadnienie ratownictwa lotniskowego zostało wybrane do rozważań nieprzypadkowo, gdyż priorytetem w założeniach ćwiczeń kompleksowych jest wypadek statku powietrznego. Na podstawie pytań zawartych w ankiecie skierowanej do strażaków PSP, biorąc pod uwagę ich udział w ćwiczeniach służb ratowniczych na lotnisku, dokonano eksploracji ich przygotowania do podjęcia działań wspierających, znajomości zasad współpracy ze służbami lotniskowymi, a także potrzeb szkoleniowych w zakresie ratownictwa lotniskowego.

\section{Metodologia badań}

\subsection{Przedmiot i cel badań}

Przedmiotem badań autor uczynił ćwiczenia kompleksowe na lotnisku ze scenariuszem wypadku statku powietrznego, a także przygotowanie strażaków Państwowej Straży Pożarnej do udziału w działaniach ratowniczych na terenie portu lotniczego oraz w jego rejonie operacyjnym po wypadku statku powietrznego.

Celem teoretyczno-poznawczym, jaki autor przyjął, było zebranie informacji sondażowych od strażaków PSP na temat poziomu ich przygotowania do udziału w działaniach ratowniczych po wypadku statku powietrznego oraz sposobu postrzegania przez nich ćwiczeń kompleksowych jako elementu w procesie ich doskonalenia zawodowego. 
Artur Musiał - Ćwiczenia kompleksowe na lotnisku...

Grupę badanych z racji specyficznego ulokowania w stosunku do Lotniska Katowice-Pyrzowice stanowili strażacy Jednostek Ratowniczo-Gaśniczych ${ }^{12}$ PSP w Będzinie i Zawierciu.

\subsection{Problemy i hipotezy badawcze}

W niniejszym artykule autor wyróżnił następujące problemy badawcze:

Problem główny: Czy obecnie stosowany system szkolenia strażaków Państwowej Straży Pożarnej daje im przynajmniej minimalną wiedzę potrzebną do podjęcia skutecznych działań ratowniczych w przypadku zaistnienia wypadku statku powietrznego?

Problemy szczegółowe:

- Jakie są źródła wiedzy na temat ratownictwa lotniskowego strażaków Państwowej Straży Pożarnej?

- Czy strażacy Państwowej Straży Pożarnej znają zasady prowadzenia działań ratowniczych na lotnisku w stopniu umożliwiającym ich skuteczne podjęcie?

- Czy strażacy Państwowej Straży Pożarnej odczuwają potrzebę uczestniczenia w ćwiczeniach kompleksowych na lotnisku?

- Jakich rezultatów oczekują strażacy Państwowej Straży Pożarnej po wzięciu udziału w ćwiczeniach kompleksowych na lotnisku?

$\mathrm{Na}$ podstawie analizy obowiązujących przepisów, wiedzy własnej i doświadczenia zawodowego autora artykułu zostały sformułowane następujące hipotezy badawcze:

Hipoteza ogólna: Strażacy Państwowej Straży Pożarnej odczuwają potrzebę doskonalenia zawodowego w zakresie ratownictwa lotniskowego, gdyż ich system szkolenia obejmuje te zagadnienia w minimalnym stopniu.

12 Jednostka Ratowniczo-Gaśnicza (JRG) jest komórką organizacyjną Komendy Powiatowej/Miejskiej Państwowej Straży Pożarnej, wyposażoną w specjalistyczny sprzęt do walki z pożarami, klęskami żywiołowymi i innymi miejscowymi zagrożeniami. JRG składa się z osób pełniących służbę zawodową na podstawie stosunku służbowego definicja własna na podstawie art. 1 ust. 1 i art. 8 . ust. 2 ustawy o Państwowej Straży Pożarnej. 
Hipotezy szczegółowe:

- Ćwiczenia kompleksowe na lotnisku są jednym ze źródeł wiedzy strażaków Państwowej Straży Pożarnej w temacie ratownictwa lotniskowego.

- Znajomość zasad prowadzenia działań ratowniczych na lotnisku przez strażaków Państwowej Straży Pożarnej kształtuje się na średnim poziomie.

- Strażacy Państwowej Straży Pożarnej odczuwają potrzebę uczestniczenia w ćwiczeniach kompleksowych na lotnisku.

- Strażacy Państwowej Straży Pożarnej postrzegają uczestnictwo w ćwiczeniach kompleksowych jako przydatny element doskonalenia zawodowego.

- System szkolenia strażaków Państwowej Straży Pożarnej w zakresie ratownictwa lotniskowego powinien zawierać większą liczbę godzin zajęć teoretycznych i praktycznych.

\subsection{Metody, techniki i narzędzia badawcze}

Uzyskanie możliwości weryfikacji powyższych hipotez determinuje dobranie adekwatnych metod i technik badawczych, opracowanie narzędzi do przeprowadzenia badań oraz prawidłowe ich przeprowadzenie.

Do celów badawczych autor zastosował metodę sondażu diagnostycznego z techniką ankiety i narzędziem w postaci kwestionariusza skierowanego do dwóch grup respondentów stanowiących jedną grupę zawodową.

\section{2. Ćwiczenia służb ratowniczych na lotnisku}

Przepisy we wszystkich trzech obszarach oddziaływania prawa nakładają na operatora ${ }^{13}$ lotniska obowiązek opracowania planu działa-

13 Pojęcie „operator” używane jest w prawie unijnym. W ustawodawstwie polskim odpowiada mu pojęcie „zarządzający” 
Artur Musiał - Ćwiczenia kompleksowe na lotnisku...

nia w sytuacji zagrożenia dla lotniska (PDSZ). Plan ten powinien stanowić ramy postępowania, umożliwiając służbom ratowniczym, medycznym, ochrony oraz pozostałym służbom portu lotniczego, a także podmiotom zewnętrznym w efektywny i skoordynowany sposób reagowanie na sytuacje zagrożenia na lotnisku. Obowiązkiem podmiotu zarządzającego portem lotniczym jest opracowanie i wdrożenie procedury na okresowe testowanie adekwatności PDSZ i przegląd wyników testu w celu poprawy jego skuteczności. Narzędziem służącym do tego jest organizacja i przeprowadzenie ćwiczeń. Rodzaje i czasookresy przeprowadzania ćwiczeń działania w sytuacjach zagrożenia ${ }^{14}$ zebrano w Tabeli 1.

Tabela 1. Rodzaje ćwiczeń działania w sytuacjach zagrożenia w porcie lotniczym

\begin{tabular}{|l|l|}
\hline Rodzaj ćwiczeń & \multicolumn{1}{c|}{ Czasookres przeprowadzenia } \\
\hline Kompleksowe & nie rzadziej niż co dwa lata \\
\hline Częściowe & w ciągu roku po danym ćwiczeniu kompleksowym \\
\hline $\begin{array}{l}\text { sztabowe } \\
\text { (teoretyczne) }\end{array}$ & $\begin{array}{l}\text { przynajmniej raz na sześć miesięcy z wyjątkiem tego okresu } \\
\text { sześciomiesięcznego, w którym przeprowadzono ćwiczenia } \\
\text { kompleksowe }\end{array}$ \\
\hline
\end{tabular}

Źródło: Opracowanie własne na podstawie obowiązujących przepisów.

Cele ćwiczeń działania w sytuacjach zagrożenia najprościej określić można jako sprawdzenie:

\footnotetext{
14 Doc 9137-AN/898 Podręcznik służb lotniskowych Część 7 Planowanie działań w sytuacjach zagrożenia $w$ porcie lotniczym, „Wytyczne nr 11 Prezesa Urzędu Lotnictwa Cywilnego z dnia 22 września 2016 r. w sprawie wprowadzenia do stosowania wymagań ustanowionych przez Organizację Międzynarodowego Lotnictwa Cywilnego (ICAO) - Doc 9137-AN/898 Część 1 i 7" (Dz. Urz. ULC 2016, poz. 76), s. 56.

AMC1 ADR.OPS.B.005(c), GM2 ADR.OPS.B.005(c), Łatwo dostępne przepisy dla lotnisk (Rozporządzenie (UE) nr 139/2014) wersja w języku polskim opublikowana na podstawie dokumentu EASA: Easy Acces Rules For Aerodromes (Regulation (EU) No 139/2014), EASA maj 2019, https://www.ulc.gov.pl/_download/lotniska/Latwo_dost epne_przepisy_dla_lotnisk_pl_28.06.2019.pdf, [dostęp: 12-04-2019].

$\S 20$ ust. 4 pkt $1-3$ rozporządzenia Ministra Transportu, Budownictwa i Gospodarki Morskiej z dnia 4 kwietnia 2013 r. w sprawie przygotowania lotnisk do sytuacji zagrożenia oraz lotniskowych służb ratowniczo-gaśniczych (Dz.U. 2013, poz. 487).
} 
- reakcji wszystkich służb biorących udział w działaniach ratowniczych,

- planów i procedur działania w sytuacjach zagrożenia,

- wyposażenia ratowniczego i środków łączności.

Sprawdzenie poprzez ćwiczenia poprawności procedur zawartych w PDSZ ma kluczowe znaczenie dla wskazania potencjalnych poważnych luk w jego treści. Organizacja ćwiczeń umożliwia służbom lotniskowym podejmującym działania w sytuacji zagrożenia głębszą integrację i wzajemne poznanie swoich sposobów działania. Służbom zewnętrznym zaś stwarza możliwość zapoznania się z infrastrukturą lotniska, doskonalenia współpracy z personelem lotniskowym oraz dokładniejsze zidentyfikowanie obszarów zagrożenia. Dążyć należy do organizacji ćwiczeń zarówno w porze dziennej jak i w nocy oraz w różnych warunkach atmosferycznych, aby w sposób dokładny odwzorować sytuację zagrożenia na lotnisku.

O ile ideą ćwiczeń częściowych i sztabowych jest sprawdzenie tylko niewielkiego fragmentu działań w sytuacji zagrożenia, o tyle sprawdzenia PDSZ we wszystkich obszarach działania w konkretnej sytuacji dokonuje się poprzez przeprowadzenie ćwiczeń kompleksowych. Elementy, na weryfikację których zwracana jest szczególna uwaga to: procedury działania, stan techniczny i poprawność działania urządzeń i wyposażenia oraz czas reakcji podmiotów uczestniczących w ćwiczeniach. Ćwiczenia kompleksowe kończy pełne sprawozdanie ze szczegółową analizą i oceną krytyczną. Przyjętą zasadą jest aktywne uczestnictwo przedstawicieli wszystkich podmiotów biorących udział w ćwiczeniach w przygotowaniu analizy i oceny krytycznej.

\section{Charakterystyka terenu badawczego i organizacja przebiegu badań}

Do badań zostali wybrani strażacy z dwóch spośród dziesięciu JRG PSP przewidzianych do udziału w działaniach ratowniczych na Lotnisku Katowice-Pyrzowice na podstawie rozkazu Śląskiego Komendanta 
Artur Musiał - Ćwiczenia kompleksowe na lotnisku...

Wojewódzkiego PSP. Ze statystyk zamieszczonych w Tabeli 2 wynika, że prawdopodobieństwo wypadku statku powietrznego w rejonie podejścia do lądowania jest stosunkowo duże w stosunku do pozostałych faz lotu.

Tabela 2. Zestawienie liczby wypadków i ofiar śmiertelnych w poszczególnych fazach lotu w przedziale czasowym od 2008 do 2017 r.

\begin{tabular}{|c|c|c|c|c|c|c|c|c|c|}
\hline & \multicolumn{9}{|c|}{ Faza lotu } \\
\hline & $\begin{array}{l}\overline{0} \\
\overline{8} \\
0 \\
0\end{array}$ & $\underset{\tilde{\omega}}{\tilde{\omega}}$ & 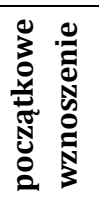 & 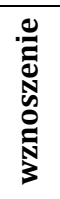 & 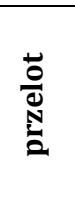 & 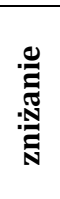 & 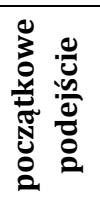 & 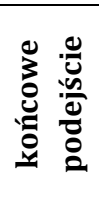 & 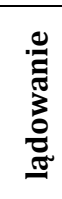 \\
\hline Wypadki & 5 & 4 & 4 & 3 & 6 & 2 & 4 & 15 & 12 \\
\hline $\begin{array}{l}\text { Ofiary } \\
\text { śmiertelne }\end{array}$ & 0 & 180 & 18 & 92 & 515 & 74 & 399 & 730 & 273 \\
\hline
\end{tabular}

Źródło: opracowanie własne na podstawie: Statistical Summary of Commercial Jet Airplane Accidents Worldwide Operations (1959-2017), http://www.boeing.com/resources/boeingdotcom/company/about_bca/pdf /statsum.pdf [dostęp:12-04-2019].

Stąd też głównym i nieprzypadkowym powodem wytypowania przez autora do badań strażaków z tych dwóch jednostek był wzgląd na zasadniczy kierunek podejścia do lądowania dla Lotniska KatowicePyrzowice przebiegający nad terenem powiatu będzińskiego i zawierciańskiego, a więc nad terenem działania JRG Będzin i JRG Zawiercie.

W okresie 1-30 września 2017 r. za zgodą komendantów powiatowych PSP w Będzinie i Zawierciu przeprowadzone zostało badanie ankietowe na terenie jednostek ratowniczo-gaśniczych należących do tychże komend. Przyjęty okres jednego miesiąca miał na celu umożliwienie udziału w badaniu jak największej liczbie funkcjonariuszy. Grupę badanych stanowili strażacy w zdecydowanej większości pełniący służbę w podziale bojowym. Jako zmienne wykorzystane zostały: płeć respondentów, ich wiek, staż służby w PSP, stopień służbowy, zajmowane stanowisko oraz przynależność do komendy powiatowej PSP. 


\section{Prezentacja i analiza wyników badań}

Do ankietera spłynęło 46 ankiet z JRG Będzin i 38 z JRG Zawiercie, co dało w sumie 84 ankiety. W badaniu udział wzięli tylko mężczyźni. W Tabeli 3 dokonano zestawienia informacji zawartych w metryczce ankiety.

Tabela 3. Zestawienie informacji zawartych w metryczce

\begin{tabular}{|c|c|c|c|c|c|c|c|c|c|}
\hline & \multicolumn{8}{|c|}{ Przedział wiekowy } & \multirow[b]{2}{*}{ Razem } \\
\hline $\mathrm{JRG}$ & $20-25$ & \multicolumn{2}{|c|}{$26-30$} & $31-35$ & $36-40$ & \multicolumn{2}{|c|}{$41-45$} & $\begin{array}{c}\text { powyżej } \\
45\end{array}$ & \\
\hline Będzin & 1 & \multicolumn{2}{|c|}{12} & 14 & 11 & & 6 & 2 & 46 \\
\hline Zawiercie & 3 & \multicolumn{2}{|c|}{3} & 16 & 12 & & 3 & 1 & 38 \\
\hline Razem & 4 & \multicolumn{2}{|c|}{15} & 30 & 23 & & 9 & 3 & 84 \\
\hline & \multicolumn{8}{|c|}{ Staż służby } & \\
\hline JRG & $\begin{array}{l}\text { poniżej } \\
1 \text { roku }\end{array}$ & \multicolumn{2}{|c|}{$1-5$} & $6-10$ & $11-15$ & \multicolumn{2}{|c|}{$16-20$} & $\begin{array}{c}\text { powyżej } \\
20 \\
\end{array}$ & Razem \\
\hline Będzin & 0 & \multicolumn{2}{|c|}{5} & 23 & 12 & & 2 & 4 & 46 \\
\hline Zawiercie & 0 & \multicolumn{2}{|c|}{4} & 15 & 13 & & 4 & 2 & 38 \\
\hline Razem & 0 & \multicolumn{2}{|c|}{9} & 38 & 25 & & 6 & 6 & 84 \\
\hline & \multicolumn{8}{|c|}{ Korpus } & \\
\hline JRG & \multicolumn{2}{|c|}{ szeregowych } & \multicolumn{2}{|c|}{ podoficerów } & \multicolumn{2}{|c|}{ aspirantów } & \multicolumn{2}{|c|}{ oficerów } & Razem \\
\hline Będzin & \multicolumn{2}{|c|}{0} & \multicolumn{2}{|c|}{29} & \multicolumn{2}{|c|}{10} & \multicolumn{2}{|c|}{7} & 46 \\
\hline Zawiercie & \multicolumn{2}{|l|}{0} & \multicolumn{2}{|c|}{28} & \multicolumn{2}{|l|}{9} & \multicolumn{2}{|r|}{1} & 38 \\
\hline \multirow[t]{2}{*}{ Razem } & \multicolumn{2}{|l|}{0} & \multicolumn{2}{|c|}{57} & \multicolumn{2}{|l|}{19} & \multicolumn{2}{|r|}{8} & 84 \\
\hline & \multicolumn{8}{|c|}{ Stanowisko } & \\
\hline JRG & \multicolumn{2}{|c|}{ dowódca } & \multicolumn{2}{|c|}{$\begin{array}{l}\text { podział } \\
\text { bojowy }\end{array}$} & dyspozytc & & admi & istracyjne & Razem \\
\hline Będzin & 15 & & & & 2 & & & 1 & 46 \\
\hline Zawiercie & 10 & & & & 1 & & & 0 & 38 \\
\hline Razem & 25 & & & 5 & 3 & & & 1 & 84 \\
\hline
\end{tabular}

Źródło: badania własne

Z analizy odpowiedzi zamieszczonych w metryczce ankiety wynika, że strażacy obu jednostek stanowią doświadczoną grupę zawodową z przewagą funkcjonariuszy w wieku od 31 do 40 lat i stażem służby 
Artur Musiał - Ćwiczenia kompleksowe na lotnisku...

kształtującym się w przedziale od 6 do 15 lat. Widać również z przeglądu deklarowanego wieku i stażu służby naturalną rotację personelu. Biorąc pod uwagę stopnie służbowe i zajmowane stanowiska, zauważyć można, iż najliczniejszą i najbardziej zainteresowaną grupą, która wzięła udział w badaniu, byli przedstawiciele podziału bojowego, czyli funkcjonariusze biorący bezpośredni udział $\mathrm{w}$ działaniach ratowniczych.

Zdecydowana większość, bo 77\% ankietowanych, udzieliła prawidłowej odpowiedzi na pierwsze pytanie zamieszczone w ankiecie, dotyczące postrzegania przez nich roli PSP odgrywanej w zdarzeniach na lotnisku. Widać zatem, że strażacy są świadomi roli PSP w działaniach ratowniczych na lotnisku. Wynik badania przedstawia Tabela 4 .

Tabela 4. Świadomość ankietowanych w kwestii roli jaką pełni Państwowa Straż Pożarna w działaniach ratowniczych na lotnisku

\begin{tabular}{|l|c|c|c|c|}
\hline \multicolumn{1}{|c|}{ Wariant odpowiedzi } & $\begin{array}{c}\text { JRG } \\
\text { Będzin }\end{array}$ & $\begin{array}{c}\text { JRG } \\
\text { Zawiercie }\end{array}$ & Razem & $\begin{array}{c}\text { Ujęcie } \\
\text { procentowe }\end{array}$ \\
\hline jest służbą wiodącą & 11 & 8 & 19 & $23 \%$ \\
\hline jest służbą pomocniczą & 35 & 30 & 65 & $77 \%$ \\
\hline $\begin{array}{l}\text { nie odgrywa żadnej roli, } \\
\text { bo LSR-G jest w stanie } \\
\text { samodzielnie zapewnić } \\
\text { bezpieczeństwo }\end{array}$ & 0 & 0 & 0 & $0 \%$ \\
\hline
\end{tabular}

Źródło: badania własne

Odpowiedzi udzielone na pytanie drugie (zestawienie w Tabeli 5.) nakreślają deklarowany przez ankietowanych poziom ich wiedzy w zakresie ratownictwa lotniskowego. Tylko 33\% z ankietowanych określa poziom swojej wiedzy jako wystarczający. Liczba odpowiedzi z deklaracją braku odpowiedniego poziomu wiedzy (w interpretacji autora odpowiedzi: raczej niewystarczający - 13\% i niewystarczający - 1\%) oraz odpowiedzi z poczuciem niepewności co do poziomu posiadanej wiedzy (raczej wystarczający - 54\%) świadczy o odczuwaniu przez 
strażaków potrzeby poszerzenia swych wiadomości z zakresu ratownictwa lotniskowego.

Tabela 5. Świadomość ankietowanych w kwestii roli jaką pełni Państwowa Straż Pożarna w działaniach ratowniczych na lotnisku

\begin{tabular}{|l|c|c|c|c|}
\hline Wariant odpowiedzi & $\begin{array}{c}\text { JRG } \\
\text { Będzin }\end{array}$ & $\begin{array}{c}\text { JRG } \\
\text { Zawiercie }\end{array}$ & Razem & $\begin{array}{c}\text { Ujęcie } \\
\text { procentowe }\end{array}$ \\
\hline wystarczający & 16 & 12 & 28 & $33 \%$ \\
\hline raczej wystarczający & 22 & 23 & 45 & $77 \%$ \\
\hline $\begin{array}{l}\text { raczej } \\
\text { niewystraczający }\end{array}$ & 8 & 2 & 10 & $54 \%$ \\
\hline niewystarczający & 0 & 1 & 1 & $1 \%$ \\
\hline
\end{tabular}

Źródło: badania własne

W odpowiedzi na pytanie trzecie ankietowani podali źródła czerpania wiedzy na temat ratownictwa lotniskowego. Konstrukcja pytania pozwalała dokonać wielokrotnego wyboru spośród sześciu proponowanych przez autora odpowiedzi, a także podać własne źródła. Zestawienie odpowiedzi przedstawiono w Tabeli 6. Jako własne źródła ankietowani wskazali:

- szkolenia na lotnisku,

- Internet,

- pracę w LSR-G.

Z interpretacji udzielonych odpowiedzi można wysnuć wniosek, że udział w ćwiczeniach na lotnisku jest $\mathrm{u}$ ankietowanych jednym $\mathrm{z}$ bardziej cenionych źródeł wiedzy. Tezę tę popiera także wariant udzielonych odpowiedzi własnych, wśród których również wymienia się szkolenia na lotnisku, a także wcześniejszą pracę w LSR-G. Sądząc po ilości wskazań opcji samodoskonalenia i Internetu jako źródła wiedzy (odpowiedź własna), należy stwierdzić, że ankietowani interesują się zagadnieniem ratownictwa lotniskowego i w sposób ciągły, nawet indywidualnie poszukują wiadomości na ten temat. 
Artur Musiał - Ćwiczenia kompleksowe na lotnisku...

Tabela 6. Źródła wiedzy ankietowanych na temat ratownictwa lotniskowego

\begin{tabular}{|l|c|c|c|}
\hline \multicolumn{1}{|c|}{ Wariant odpowiedzi } & $\begin{array}{c}\text { JRG } \\
\text { Będzin }\end{array}$ & $\begin{array}{c}\text { JRG } \\
\text { Zawiercie }\end{array}$ & Razem \\
\hline odbyte kursy w PSP & 19 & 18 & 37 \\
\hline udział w ćwiczeniach na lotnisku & 16 & 16 & 32 \\
\hline Szkoła Aspirantów PSP & 14 & 6 & 20 \\
\hline Szkoła Podoficerska PSP & 4 & 8 & 12 \\
\hline Szkoła Główna Służby Pożarniczej & 3 & 2 & 5 \\
\hline Samodoskonalenie & 8 & 5 & 12 \\
\hline inne, wskazane przez ankietowanych & 3 & 0 & 3 \\
\hline
\end{tabular}

Źródło: badania własne

Pytanie czwarte dotyczyło znajomości pojęcia ćwiczeń kompleksowych organizowanych na lotnisku. Udzielone odpowiedzi (zestawienie w Tabeli 7) świadczą o znajomości tego pojęcia przez większość strażaków PSP. Fakt ten można zinterpretować jako stosunkowo dobre przygotowanie teoretyczne.

Tabela 7. Znajomość pojęcia ćwiczeń kompleksowych deklarowana przez ankietowanych

\begin{tabular}{|c|c|c|c|c|}
\hline $\begin{array}{c}\text { Wariant } \\
\text { odpowiedzi }\end{array}$ & $\begin{array}{c}\text { JRG } \\
\text { Będzin }\end{array}$ & $\begin{array}{c}\text { JRG } \\
\text { Zawiercie }\end{array}$ & Razem & $\begin{array}{c}\text { Ujęcie } \\
\text { procentowe }\end{array}$ \\
\hline Tak & 38 & 33 & 71 & $85 \%$ \\
\hline Nie & 8 & 5 & 13 & $15 \%$ \\
\hline
\end{tabular}

Źródło: badania własne

W pytaniu piątym zapytano o udział respondenta w ćwiczeniach kompleksowych na lotnisku. Wynik badania zamieszczono w Tabeli 8. Wynik badania wskazuje, że niewiele ponad $50 \%$ personelu $\mathrm{z}$ badanych jednostek brało udział w tego rodzaju ćwiczeniach. Taki stan rzeczy może tłumaczyć dynamiczny w ostatnim czasie proces wymiany kadr w PSP lub migracja personelu $\mathrm{z}$ innych jednostek ratowniczogaśniczych, nie przewidzianych do działań na lotnisku. 
Tabela 8. Udział w ćwiczeniach kompleksowych deklarowana przez ankietowanych

\begin{tabular}{|c|c|c|c|c|}
\hline $\begin{array}{c}\text { Wariant } \\
\text { odpowiedzi }\end{array}$ & JRG Będzin & $\begin{array}{c}\text { JRG } \\
\text { Zawiercie }\end{array}$ & Razem & $\begin{array}{c}\text { Ujęcie } \\
\text { procentowe }\end{array}$ \\
\hline Tak & 25 & 21 & 46 & $55 \%$ \\
\hline Nie & 27 & 11 & 38 & $45 \%$ \\
\hline
\end{tabular}

Źródło: badania własne

Pytanie szóste ukierunkowane było na poznanie poziomu odczuwania przez ankietowanych potrzeby uczestnictwa w ćwiczeniach kompleksowych na lotnisku. W odpowiedziach udzielonych na to pytanie wyraźnie dostrzec można potrzebę strażaków PSP uczestnictwa w tych ćwiczeniach. Zestawienie udzielonych odpowiedzi zawarto w Tabeli 9.

Tabela 9. Odczuwanie przez ankietowanych potrzeby uczestnictwa w ćwiczeniach kompleksowych na lotnisku

\begin{tabular}{|c|c|c|c|c|}
\hline $\begin{array}{c}\text { Wariant } \\
\text { odpowiedzi }\end{array}$ & $\begin{array}{c}\text { JRG } \\
\text { Będzin }\end{array}$ & $\begin{array}{c}\text { JRG } \\
\text { Zawiercie }\end{array}$ & Razem & $\begin{array}{c}\text { Ujęcie } \\
\text { procentowe }\end{array}$ \\
\hline Tak & 38 & 8 & 46 & $55 \%$ \\
\hline Nie & 34 & 4 & 38 & $45 \%$ \\
\hline
\end{tabular}

Źródło: badania własne

Nie sposób pominąć dwóch uzasadnień, o które poprosił autor w przypadku braku deklaracji potrzeby uczestnictwa w ćwiczeniach kompleksowych. W pierwszym przypadku odpowiedzi udzielił dyspozytor stanowiska kierowania. Swoje odczucie uzasadnił brakiem udziału w czynnych działaniach ratowniczych. Drugi zaś wariant: przekonanie o wystarczającym zakresie obowiązków służbowych (pisownia oryginalna zmieniona przez autora z zachowaniem treści merytorycznej), nie rozwinięte w pełni, zinterpretować można jako przejaw wypalenia zawodowego respondenta i uznać za marginalną wartość w odniesieniu do całości badania.

W pytaniu siódmym poruszony został temat odwzorowania przez ćwiczenia kompleksowe realnej sytuacji zagrożenia na lotnisku. Analizując wszystkie udzielone odpowiedzi zawarte w Tabeli 10, można 
Artur Musiał - Ćwiczenia kompleksowe na lotnisku...

zauważyć, że strażacy PSP postrzegają odwzorowanie realnej sytuacji zagrożenia na lotnisku przez ćwiczenia kompleksowe jako prawidłowe - przewaga odpowiedzi w wariancie „Tak” i „Raczej tak”. Można zatem założyć, że strażacy PSP, którzy brali udział w ćwiczeniach kompleksowych, tworzą dla tych, którzy nie mieli okazji w nich uczestniczyć, pozytywny przekaz odbioru ćwiczeń. Wynik badania wskazuje również na wyrobioną pozytywną opinię wśród ankietowanych na temat organizacji tychże ćwiczeń.

Tabela 10. Opinia ankietowanych w kwestii odwzorowania przez ćwiczenia kompleksowe realnej sytuacji zagrożenia na lotnisku

\begin{tabular}{|c|c|c|c|c|}
\hline $\begin{array}{c}\text { Wariant } \\
\text { odpowiedzi }\end{array}$ & $\begin{array}{c}\text { JRG } \\
\text { Będzin }\end{array}$ & $\begin{array}{c}\text { JRG } \\
\text { Zawiercie }\end{array}$ & Razem & $\begin{array}{c}\text { Ujęcie } \\
\text { procentowe }\end{array}$ \\
\hline Tak & 21 & 15 & 36 & $43 \%$ \\
\hline Raczej tak & 10 & 18 & 28 & $33 \%$ \\
\hline Raczej nie & 9 & 4 & 13 & $16 \%$ \\
\hline Nie & 6 & 1 & 7 & $8 \%$ \\
\hline
\end{tabular}

Źródło: badania własne

Temat oceny zasadności przeprowadzania ćwiczeń kompleksowych na lotnisku z punktu widzenia doskonalenia zawodowego strażaków PSP zawiera pytanie ósme. Pytanie to należy do grupy zamkniętych z czterema wariantami odpowiedzi. Wynik badania ujęto w Tabeli 11. Ze zdecydowanej większości udzielonych odpowiedzi w wariancie „Tak” i „Raczej tak” wynika postrzeganie ćwiczeń kompleksowych za element przydatny i pożądany do ujęcia w planie doskonalenia zawodowego strażaków PSP. 
Tabela 11. Zasadność przeprowadzania ćwiczeń kompleksowych na lotnisku z punktu widzenia doskonalenia zawodowego strażaków PSP

\begin{tabular}{|c|c|c|c|c|}
\hline $\begin{array}{c}\text { Wariant } \\
\text { odpowiedzi }\end{array}$ & $\begin{array}{c}\text { JRG } \\
\text { Będzin }\end{array}$ & $\begin{array}{c}\text { JRG } \\
\text { Zawiercie }\end{array}$ & Razem & $\begin{array}{c}\text { Ujęcie } \\
\text { procentowe }\end{array}$ \\
\hline Tak & 33 & 19 & 52 & $62 \%$ \\
\hline Raczej tak & 11 & 17 & 28 & $33 \%$ \\
\hline Raczej nie & 1 & 1 & 2 & $1,68 \%$ \\
\hline Nie & 1 & 1 & 2 & $1,68 \%$ \\
\hline
\end{tabular}

Źródło: badania własne

W dziewiątym pytaniu respondenci za pomocą odpowiedzi „Tak” lub „Nie” wyrazili opinie na temat umieszczenia ćwiczeń kompleksowych jako stałego elementu rocznego planu doskonalenia zawodowego realizowanego w jednostkach Państwowej Straży Pożarnej. Można także było uzasadnić odpowiedź negatywną. Zestawienie odpowiedzi zawiera Tabela 12 .

Tabela 12. Opinia respondentów w kwestii umieszczenia ćwiczeń kompleksowych jako stałego elementu rocznego planu doskonalenia zawodowego realizowanego w jednostkach Państwowej Straży Pożarnej

\begin{tabular}{|c|c|c|c|c|}
\hline $\begin{array}{c}\text { Wariant } \\
\text { odpowiedzi }\end{array}$ & $\begin{array}{c}\text { JRG } \\
\text { Będzin }\end{array}$ & $\begin{array}{c}\text { JRG } \\
\text { Zawiercie }\end{array}$ & Razem & $\begin{array}{c}\text { Ujęcie } \\
\text { procentowe }\end{array}$ \\
\hline Tak & 38 & 8 & 46 & $86 \%$ \\
\hline Nie & 34 & 4 & 38 & $14 \%$ \\
\hline
\end{tabular}

Źródło: badania własne

Po przeanalizowaniu odpowiedzi wyraźnie widać u strażaków PSP świadomość powagi zagadnień ratownictwa lotniskowego i chęć posiadania przez nich ćwiczeń kompleksowych w rocznym planie doskonalenia zawodowego. W przypadku wyboru odpowiedzi „Nie” autor poprosił o krótkie uzasadnienie. Tylko dwóch ankietowanych uzasadniło swój wybór. Argumenty, jakich użyto, to: 
Artur Musiał - Ćwiczenia kompleksowe na lotnisku...

- nie wnoszą nic nowego,

- ćwiczenia co rok to zbyt często.

Autor założył, że odpowiedzi tych udzielili strażacy z wieloletnim stażem służby. W pewnych okolicznościach można przyznać im rację, ale spoglądając na zagadnienie z punktu widzenia strażaków mniej doświadczonych zawodowo i wyrażonych opinii w ankiecie, trzeba stwierdzić, że uzasadnienia te nie powinny wystąpić.

Inne spojrzenie na ćwiczenia kompleksowe rzuca pytanie dziesiąte. Ankietowani wyrazili w nim opinię na temat przydatności ćwiczeń kompleksowych do planowania działań przez PSP na wypadek sytuacji zagrożenia na lotnisku. Wynik badania zestawiono w Tabeli 13. Analiza udzielonych odpowiedzi pokazuje, że zdecydowana większość strażaków PSP dostrzega związek tych dwóch przedsięwzięć i kwalifikuje ćwiczenia kompleksowe jako narzędzie pomocne w planowaniu działań na wypadek sytuacji zagrożenia na lotnisku.

Tabela 13. Opinia ankietowanych na temat przydatności ćwiczeń kompleksowych w planowaniu działań przez PSP na wypadek sytuacji zagrożenia na lotnisku

\begin{tabular}{|c|c|c|c|c|}
\hline $\begin{array}{c}\text { Wariant } \\
\text { odpowiedzi }\end{array}$ & JRG Będzin & $\begin{array}{c}\text { JRG } \\
\text { Zawiercie }\end{array}$ & Razem & $\begin{array}{c}\text { Ujęcie } \\
\text { procentowe }\end{array}$ \\
\hline Tak & 33 & 20 & 53 & $63 \%$ \\
\hline Raczej tak & 9 & 16 & 25 & $30 \%$ \\
\hline Raczej nie & 2 & 1 & 3 & $3,5 \%$ \\
\hline Nie & 2 & 1 & 3 & $3,5 \%$ \\
\hline
\end{tabular}

Źródło: badania własne

W jedenastym pytaniu ankietowani wyrazili swoje zdanie w kwestii częstotliwości przeprowadzania ćwiczeń kompleksowych. Autor przewidział dwie podstawowe odpowiedzi. Odpowiedź „Tak” należało uzupełnić jednym z czterech wariantów odpowiedzi, natomiast odpowiedź „Nie" jest traktowana jako uznanie obecnej częstotliwości - raz na dwa lata - jako wystarczającej. W Tabeli 14 zebrano wstępne wyniki bada- 
nia dla odpowiedzi podstawowych, natomiast odpowiedzi uzupełniające z podanymi czasookresami przedstawiono w Tabeli 15.

Tabela 14. Opinia ankietowanych na temat zmiany częstotliwości przeprowadzania ćwiczeń kompleksowych

\begin{tabular}{|c|c|c|c|c|}
\hline $\begin{array}{c}\text { Wariant } \\
\text { odpowiedzi }\end{array}$ & JRG Będzin & $\begin{array}{c}\text { JRG } \\
\text { Zawiercie }\end{array}$ & Razem & $\begin{array}{c}\text { Ujęcie } \\
\text { procentowe }\end{array}$ \\
\hline Tak & 31 & 25 & 56 & $67 \%$ \\
\hline Nie & 15 & 13 & 28 & $33 \%$ \\
\hline
\end{tabular}

Źródło: badania własne

Tabela 15. Proponowany przez ankietowanych czasookres przeprowadzania ćwiczeń kompleksowych na lotnisku

\begin{tabular}{|l|c|c|c|c|}
\hline $\begin{array}{c}\text { Wariant } \\
\text { odpowiedzi }\end{array}$ & JRG Będzin & $\begin{array}{c}\text { JRG } \\
\text { Zawiercie }\end{array}$ & Razem & $\begin{array}{c}\text { Ujęcie } \\
\text { procentowe }\end{array}$ \\
\hline raz na rok & 23 & 16 & 39 & $70 \%$ \\
\hline raz na trzy lata & 7 & 8 & 15 & $27 \%$ \\
\hline raz na cztery lata & 0 & 1 & 1 & $1,5 \%$ \\
\hline raz na pięć lat & 1 & 0 & 1 & $1,5 \%$ \\
\hline
\end{tabular}

Źródło: badania własne

Z powyższego wynika, że strażacy PSP odczuwają potrzebę częstszego udziału w ćwiczeniach kompleksowych na lotnisku. Dowodzi tego sugestia większości z nich zmiany częstotliwości przeprowadzania ćwiczeń z okresu dwuletniego na roczny. Może to być spowodowane naturalną rotacją personelu, a także chęcią poznania nowej rzeczywistości przez personel mniej doświadczony zawodowo.

Określenie w skali 1 - 7 priorytetu dla elementów, na które należy zwrócić uwagę podczas przeprowadzania ćwiczeń kompleksowych na lotnisku, było zagadnieniem zawartym w pytaniu dwunastym. Elementy te odnoszą się do strefy zagrożenia, a więc do obszaru, do którego mają dostęp tylko służby ratownicze. Autor przyjął skalę, w której „1” oznacza największy priorytet, a „7" - priorytet najmniejszy. Ankietowa- 
Artur Musiał - Ćwiczenia kompleksowe na lotnisku...

ni mieli możliwość podania również własnych propozycji. Nikt z nich nie skorzystał jednak z tej możliwości. Wynik badania zestawiono w Tabeli 16.

Tabela 16. Ocena priorytetu dla elementów ćwiczeń

\begin{tabular}{|l|c|c|c|c|c|c|c|}
\hline \multirow{2}{*}{ Element } & \multicolumn{7}{|c|}{ Skala oceny } \\
\cline { 2 - 8 } & $\mathbf{1}$ & $\mathbf{2}$ & $\mathbf{3}$ & $\mathbf{4}$ & $\mathbf{5}$ & $\mathbf{6}$ & $\mathbf{7}$ \\
\hline $\begin{array}{l}\text { działania } \\
\text { gaśnicze }\end{array}$ & $\begin{array}{c}15 \\
(10 ; 5)\end{array}$ & $\begin{array}{c}18 \\
(12 ; 6)\end{array}$ & $\begin{array}{c}28 \\
(11 ; 17)\end{array}$ & $\begin{array}{c}11 \\
(7 ; 4)\end{array}$ & $\begin{array}{c}5 \\
(3 ; 2)\end{array}$ & $\begin{array}{c}5 \\
(1 ; 4)\end{array}$ & $\begin{array}{c}2 \\
(2 ; 0)\end{array}$ \\
\hline $\begin{array}{l}\text { działania } \\
\text { ratownicze }\end{array}$ & $\begin{array}{c}26 \\
(21 ; 5)\end{array}$ & $\begin{array}{c}36 \\
(15 ; 21)\end{array}$ & $\begin{array}{c}7 \\
(3 ; 4)\end{array}$ & $\begin{array}{c}8 \\
(4 ; 4)\end{array}$ & $\begin{array}{c}4 \\
(1 ; 3)\end{array}$ & $\begin{array}{c}3 \\
(2 ; 1)\end{array}$ & $\begin{array}{c}0 \\
(0 ; 0)\end{array}$ \\
\hline $\begin{array}{l}\text { obsługa sprzętu } \\
\text { ratowniczo- } \\
\text { gaśniczego }\end{array}$ & $\begin{array}{c}0 \\
(0 ; 0)\end{array}$ & $\begin{array}{c}3 \\
(3 ; 0)\end{array}$ & $\begin{array}{c}6 \\
(2 ; 4)\end{array}$ & $\begin{array}{c}10 \\
(8 ; 2)\end{array}$ & $\begin{array}{c}13 \\
(8 ; 5)\end{array}$ & $\begin{array}{c}28 \\
(9 ; 19)\end{array}$ & $\begin{array}{c}24 \\
(16 ; 8)\end{array}$ \\
\hline $\begin{array}{l}\text { segregacja } \\
\text { poszkodowanych }\end{array}$ & $\begin{array}{c}6 \\
(2 ; 4)\end{array}$ & $\begin{array}{c}14 \\
(10 ; 4)\end{array}$ & $\begin{array}{c}21 \\
(14 ; 7)\end{array}$ & $\begin{array}{c}31 \\
(13 ; 18)\end{array}$ & $\begin{array}{c}10 \\
(6 ; 4)\end{array}$ & $\begin{array}{c}2 \\
(1 ; 1)\end{array}$ & $\begin{array}{c}0 \\
(0 ; 0)\end{array}$ \\
\hline $\begin{array}{l}\text { zaopatrywanie } \\
\text { poszkodowanych }\end{array}$ & $\begin{array}{c}2 \\
(0 ; 2)\end{array}$ & $\begin{array}{c}9 \\
(4 ; 5)\end{array}$ & $\begin{array}{c}29 \\
(10 ; 19)\end{array}$ & $\begin{array}{c}15 \\
(9 ; 6)\end{array}$ & $\begin{array}{c}32 \\
(13 ; 19)\end{array}$ & $\begin{array}{c}9 \\
(7 ; 2)\end{array}$ & $\begin{array}{c}4 \\
(3 ; 1)\end{array}$ \\
\hline $\begin{array}{l}\text { koordynacja } \\
\text { współpracy } \\
\text { służb } \\
\text { ratowniczych }\end{array}$ & $\begin{array}{l}32 \\
(11 ; 21)\end{array}$ & $\begin{array}{c}2 \\
(1 ; 1)\end{array}$ & $\begin{array}{c}8 \\
(6 ; 2)\end{array}$ & $\begin{array}{c}7 \\
(4 ; 3)\end{array}$ & $\begin{array}{c}15 \\
(11 ; 4)\end{array}$ & $\begin{array}{c}19 \\
(13 ; 6)\end{array}$ & $\begin{array}{c}1 \\
(1 ; 0)\end{array}$ \\
\hline $\begin{array}{l}\text { logistyka w } \\
\text { sytuacji } \\
\text { zagrożenia }\end{array}$ & $\begin{array}{l}3 \\
(2 ; 1)\end{array}$ & $\begin{array}{l}2 \\
(1 ; 1)\end{array}$ & $\begin{array}{c}1 \\
(0 ; 1)\end{array}$ & $\begin{array}{c}2 \\
(1 ; 1)\end{array}$ & $\begin{array}{c}4 \\
(3 ; 1)\end{array}$ & $\begin{array}{c}19 \\
(14 ; 5)\end{array}$ & $\begin{array}{c}53 \\
(25 ; 28)\end{array}$ \\
\hline $\begin{array}{l}\text { Wynik główny dla każdego z elementów stanowi sumę odpowiedzi umieszczonych w nawia- } \\
\text { sie. W pozycji pierwszej w nawiasie umieszczono liczbę odpowiedzi udzielonych przez stra- } \\
\text { żaków JRG Będzin, natomiast w pozycji drugiej liczbę odpowiedzi strażaków JRG Zawiercie. }\end{array}$ \\
\hline
\end{tabular}

Źródło: badania własne

Autor zawęził prezentację wyniku badania do trzech najważniejszych w opinii ankietowanych elementów. Z udzielonych odpowiedzi wynika, że elementem o największym priorytecie wskazanym przez strażaków jest odpowiednia koordynacja współpracy służb ratowniczych. Jako kolejne ankietowani wskazali działania ratownicze i następnie gaśnicze. Świadczyć to może o potwierdzeniu założenia z po- 
przedniego pytania, a mianowicie o potrzebie częstszego uczestniczenia strażaków PSP w ćwiczeniach na lotnisku.

Treść pytania trzynastego, na zasadzie wielokrotnego wyboru, została ukierunkowana na zbadanie rezultatów po udziale w ćwiczeniach kompleksowych na lotnisku oczekiwanych przez ankietowanych. Autor przygotował cztery gotowe odpowiedzi oraz pozostawił możliwość zamieszczenia własnych propozycji. Ankietowani korzystali tylko z oferowanych odpowiedzi. Nikt z nich nie wymienił własnych oczekiwań. Zestawienie wyników badań autor zamieścił w Tabeli 17.

Tabela 17. Rezultaty oczekiwane przez ankietowanych po udziale w ćwiczeniach kompleksowych na lotnisku

\begin{tabular}{|l|c|c|c|c|}
\hline \multicolumn{1}{|c|}{ Wariant odpowiedzi } & $\begin{array}{c}\text { JRG } \\
\text { Będzin }\end{array}$ & $\begin{array}{c}\text { JRG } \\
\text { Zawiercie }\end{array}$ & Razem & $\begin{array}{c}\text { Ujęcie } \\
\text { procentowe }\end{array}$ \\
\hline $\begin{array}{l}\text { doskonalenie już nabytych } \\
\text { umiejętności }\end{array}$ & 23 & 20 & 43 & $51 \%$ \\
\hline $\begin{array}{l}\text { wymiana doświadczeń } \\
\text { zawodowych }\end{array}$ & 13 & 15 & 28 & $33 \%$ \\
\hline $\begin{array}{l}\text { nabycie nowych } \\
\text { umiejętności }\end{array}$ & 20 & 17 & 37 & $44 \%$ \\
\hline $\begin{array}{l}\text { brak konkretnych } \\
\text { oczekiwań }\end{array}$ & 3 & 2 & 5 & $6 \%$ \\
\hline
\end{tabular}

Źródło: badania własne

Analiza wyborów wskazanych w odpowiedziach kolejny raz ukazuje pozytywny aspekt udziału w ćwiczeniach deklarowany przez strażaków PSP. Pozwoli to na dostosowanie odpowiedniego scenariusza ćwiczeń zaspokajającego ich potrzeby.

W pytaniu czternastym przygotowano sześć wariantów odpowiedzi. Poproszono w nim respondentów o wskazanie, z możliwością zaznaczenia kilku z odpowiedzi, elementów ćwiczeń, które powinny zostać szczególnie wnikliwie weryfikowane. Wyniki zebrane w Tabeli 18 pokazują, jak dużą rolę wśród ankietowanych odgrywa praktyczne działanie. Taktykę ratowniczo-gaśniczą powiązaną ze znajomością budowy statków powietrznych wskazano jako trzy kolejne elementy. 
Artur Musiał - Ćwiczenia kompleksowe na lotnisku...

Wynik ten można uznać za odzwierciedlenie chęci doskonalenia praktycznych umiejętności i poznania nowoczesnych konstrukcji statków powietrznych.

Tabela 18. Opinia ankietowanych na temat elementów ćwiczeń, które powinny zostać szczególnie wnikliwie weryfikowane podczas ćwiczeń kompleksowych

\begin{tabular}{|l|c|c|c|c|}
\hline \multicolumn{1}{|c|}{ Wariant odpowiedzi } & $\begin{array}{c}\text { JRG } \\
\text { Będzin }\end{array}$ & $\begin{array}{c}\text { JRG } \\
\text { Zawiercie }\end{array}$ & Razem & $\begin{array}{c}\text { Ujęcie } \\
\text { procentowe }\end{array}$ \\
\hline $\begin{array}{l}\text { przygotowanie teoretyczne } \\
\text { ratowników }\end{array}$ & 4 & 6 & 10 & $12 \%$ \\
\hline $\begin{array}{l}\text { umiejętności praktyczne } \\
\text { ratowników }\end{array}$ & 34 & 18 & 52 & $62 \%$ \\
\hline $\begin{array}{l}\text { wyposażenie osobiste } \\
\text { i w sprzęt ratowniczy }\end{array}$ & 6 & 5 & 11 & $13 \%$ \\
\hline $\begin{array}{l}\text { znajomość budowy statków } \\
\text { powietrznych przez } \\
\text { ratowników, możliwości } \\
\text { prowadzenia działań w ich } \\
\text { wnętrzu oraz w pobliżu }\end{array}$ & 17 & 15 & 32 & $38 \%$ \\
\hline $\begin{array}{l}\text { założenia taktyki działań } \\
\text { w odniesieniu do zaistniałej } \\
\text { sytuacji }\end{array}$ & 19 & 11 & 30 & $36 \%$ \\
\hline $\begin{array}{l}\text { kompletność oraz ilość sił } \\
\text { i środków w odniesieniu } \\
\text { do możliwych zdarzeń }\end{array}$ & 11 & 4 & 15 & $18 \%$ \\
\hline
\end{tabular}

Źródło: badania własne

Treść pytania piętnastego ma odniesienie do opinii ankietowanych na temat odpowiedniego (dobrego) przygotowania ratowników poprzez ich udział w ćwiczeniach kompleksowych na rzeczywistą sytuację zagrożenia. Autor przygotował ankietowanym cztery warianty odpowiedzi do wyboru z prośbą o jego uzasadnienie. Zestawienie dokonanych wyborów przedstawia Tabela 19, natomiast uzasadnienia autor zebrał w Tabeli 20. 
Tabela 19. Opinia osób ankietowanych w kwestii odpowiedniego (dobrego) przygotowania ratowników poprzez ćwiczenia kompleksowe na prawdziwą sytuację zagrożenia

\begin{tabular}{|c|c|c|c|c|}
\hline $\begin{array}{c}\text { Wariant } \\
\text { odpowiedzi }\end{array}$ & $\begin{array}{c}\text { JRG } \\
\text { Będzin }\end{array}$ & $\begin{array}{c}\text { JRG } \\
\text { Zawiercie }\end{array}$ & Razem & $\begin{array}{c}\text { Ujęcie } \\
\text { procentowe }\end{array}$ \\
\hline Tak & 13 & 8 & 21 & $25 \%$ \\
\hline raczej tak & 26 & 27 & 53 & $63 \%$ \\
\hline raczej nie & 5 & 4 & 9 & $11 \%$ \\
\hline Nie & 1 & 0 & 1 & $1 \%$ \\
\hline
\end{tabular}

Źródło: badania własne autora.

Tabela 20. Uzasadnienia dla poszczególnych wariantów odpowiedzi

\begin{tabular}{|c|l|}
\hline $\begin{array}{c}\text { Wariant } \\
\text { odpowiedzi }\end{array}$ & \multicolumn{1}{c|}{ Treść uzasadnienia } \\
\hline Tak & $\begin{array}{l}\text { tylko tego rodzaju ćwiczenia mogą oddać obraz realnej } \\
\text { sytuacji }\end{array}$ \\
\hline Raczej tak & $\begin{array}{l}\text { oddają (ćwiczenia - przyp. autor pracy) realną sytuację, } \\
\text { którą można zastać na miejscu zdarzenia }\end{array}$ \\
\hline Raczej nie & $\begin{array}{l}\text { ćwiczenia nie odzwierciedlają realnej sytuacji, } \\
\text { warunki podczas ćwiczeń odbiegają od rzeczywistych }\end{array}$ \\
\hline Nie & nie udzielono żadnej odpowiedzi \\
\hline
\end{tabular}

Źródło: badania własne

Autor, analizując udzielone odpowiedzi na powyższe dwa pytania, doszedł do wniosku, że sposób postrzegania przez strażaków PSP realiów prowadzenia działań ratowniczo-gaśniczych na lotnisku, zwłaszcza w sytuacji zdarzenia z udziałem statku powietrznego, jest prawidłowy. Świadczyć o tym mogą trzy najczęściej wybierane elementy ćwiczeń do szczególnej weryfikacji, czyli umiejętności praktyczne ratowników, znajomość budowy statków powietrznych przez ratowników, możliwości prowadzenia działań w ich wnętrzu oraz w pobliżu, założenia taktyki działań w odniesieniu do zaistniałej sytuacji.

Ankietowani są przekonani (większość odpowiedzi „Tak” i „Raczej tak"), że udział w ćwiczeniach kompleksowych umożliwi im w sposób 
Artur Musiał - Ćwiczenia kompleksowe na lotnisku...

odpowiedni przygotować się do działania w sytuacji realnej. Nieliczni $\mathrm{z}$ ankietowanych pokusili się o uzasadnienie swych odpowiedzi. Argumenty użyte w uzasadnieniach stanowią dowód na pozytywne postrzeganie elementu ćwiczeń kompleksowych w procesie przygotowania do mogących zaistnieć zdarzeń.

Po rozpatrzeniu uzasadnienia odpowiedzi „Raczej nie” o treści: „ćwiczenia nie odzwierciedlają realnej sytuacji, warunki podczas ćwiczeń odbiegają od rzeczywistych", autor doszedł do wniosku, że respondent nie jest w pełni pewien, czy tak jest w rzeczywistości. Spoglądając na problem przez pryzmat poziomu pozoracji, można po części zgodzić się z uzasadnieniem, gdyż działania pozoracyjne nie oddadzą mogącej zaistnieć realnie sytuacji z zastrzeżeniem jednak progu oczekiwań osoby wyrażającej swą opinię w kwestii ogólnego przygotowania środków pozoracji.

W pytaniu szesnastym poruszono zagadnienie postrzegania przez respondentów, jako istotnego elementu ćwiczeń kompleksowych, stosowania środków pozoracji w postaci makiet statków powietrznych, fantomów, pozorantów z uwidocznionymi obrażeniami, zadymienia, kontrolowanych pożarów itp. W celu dokładniejszego zbadania opinii ankietowanych autor przewidział możliwość zamieszczenia własnych uwag. Nikt jednak nie skorzystał z możliwości zamieszczenia własnych propozycji lub uwag, dlatego też w zestawieniu wyników badania pominięto tę opcję odpowiedzi (Tabela 21).

Ankietowani strażacy w sposób bardzo pozytywny odnoszą się do stosowania w ćwiczeniach środków pozoracji. Przyjąć można, że szczególnie przydatnym dla nich środkiem pozoracji byłyby makiety statków powietrznych, gdyż zdecydowana większość ankietowanych raczej nigdy nie odbyła ćwiczeń ratowniczo-gaśniczych z wykorzystaniem makiety statku powietrznego. Analizując odpowiedź drugą co do liczby wskazań (pozoracja w ograniczonym zakresie, nie powodująca dodatkowego stresu u ratowników), założyć można, że została ona wybrana przez strażaków ze stosunkowo krótkim stażem służby. Wypadki lotnicze mają to do siebie, że zazwyczaj są traumatyczne dla ratowników, co pozostawiać będzie głębokie rysy w ich psychice. Wybór chociażby 
niewielkiej liczby tego wariantu sygnalizuje fakt dostrzegania przez strażaków PSP powagi roli działań ratowniczych po wypadku lotniczym. Nie sposób jest przeprowadzić w sposób prawidłowy ćwiczeń praktycznych bez środków pozoracji, zatem fakt odejścia od środków pozoracji wybrany przez $6 \%$ ankietowanych jest w opinii autora niewykonalny i niczym nieuzasadniony.

Tabela 21. Postrzeganie stosowania środków pozoracji w postaci makiet statków powietrznych, fantomów, pozorantów z uwidocznionymi obrażeniami, zadymienia, kontrolowanych pożarów itp. jako istotnego elementu ćwiczeń kompleksowych na lotnisku

\begin{tabular}{|l|c|c|c|c|}
\hline \multicolumn{1}{|c|}{ Wariant odpowiedzi } & $\begin{array}{c}\text { JRG } \\
\text { Będzin }\end{array}$ & $\begin{array}{c}\text { JRG } \\
\text { Zawiercie }\end{array}$ & Razem & $\begin{array}{c}\text { Ujęcie } \\
\text { procentowe }\end{array}$ \\
\hline $\begin{array}{l}\text { Tak, ponieważ oddają realną } \\
\text { sytuację, z którą mogą } \\
\text { zetknąć się ratownicy }\end{array}$ & 36 & 25 & 61 & $73 \%$ \\
\hline $\begin{array}{l}\text { Tak, ale w ograniczonej } \\
\text { formie, żeby nie powodować } \\
\text { dodatkowego stresu u } \\
\text { ratowników }\end{array}$ & 4 & 6 & 10 & $12 \%$ \\
\hline $\begin{array}{l}\text { Nie, ponieważ pozoracje } \\
\text { wprowadzają tylko } \\
\text { zamieszanie, nie } \\
\text { odwzorowują realnej } \\
\text { sytuacji }\end{array}$ & 3 & 2 & 5 & $6 \%$ \\
\hline $\begin{array}{l}\text { Nie mam zdania na ten } \\
\text { temat i jest mi to obojętne }\end{array}$ & 3 & 5 & 8 & $9 \%$ \\
\hline
\end{tabular}

Źródło: badania własne

Poprzez pytanie siedemnaste ankiety autor chciał poznać opinię respondentów na temat ich udziału w ćwiczeniach w roli obserwatorów. Założono w nim brak możliwości ich czynnego udziału w ćwiczeniach. W wynikach badania, które autor zestawił w Tabeli 22, zauważyć można odczuwanie deklarowanej przez respondentów dużej potrzeby zgłębiania wiedzy w zakresie ratownictwa lotniskowego. Tylko 8\% ankietowanych zdecydowało się zdeklarować definitywny brak zainteresowania udziałem $\mathrm{w}$ ćwiczeniach $\mathrm{w}$ roli obserwatora. Dwa razy 
Artur Musiał - Ćwiczenia kompleksowe na lotnisku...

więcej, bo 16\% odpowiedzi, zaznaczono jako „Raczej nie”. Można założyć, że postąpiły tak osoby nie do końca zdecydowane. Większość z grona ankietowanych deklaruje jednak chęć udziału w ćwiczeniach w roli obserwatora. Świadczą o tym wybrane odpowiedzi: „Tak” - 32\% i „Raczej tak” - 44\%.

Tabela 22. Opinia respondentów na temat ich udziału w ćwiczeniach w roli obserwatorów w przypadku braku możliwości uczestnictwa czynnego

\begin{tabular}{|l|c|c|c|c|}
\hline $\begin{array}{c}\text { Wariant } \\
\text { odpowiedzi }\end{array}$ & $\begin{array}{c}\text { JRG } \\
\text { Będzin }\end{array}$ & $\begin{array}{c}\text { JRG } \\
\text { Zawiercie }\end{array}$ & Razem & $\begin{array}{c}\text { Ujęcie } \\
\text { procentowe }\end{array}$ \\
\hline Tak & 20 & 7 & 27 & $32 \%$ \\
\hline raczej tak & 16 & 21 & 37 & $44 \%$ \\
\hline raczej nie & 6 & 7 & 13 & $16 \%$ \\
\hline Nie & 4 & 3 & 7 & $8 \%$ \\
\hline
\end{tabular}

Źródło: badania własne

Pytanie osiemnaste zostało powiązane tematycznie z poprzednim. Dotyczy ono udziału ankietowanego w ćwiczeniach w roli obserwatora i dostrzegania $\mathrm{w}$ związku z tym korzyści dla siebie jako pełniącego tę funkcję. Wyrażone na ten temat opinie przedstawione zostały w Tabeli 23.

Tabela 23. Opinia na temat dostrzegania korzyści dla siebie w związku z pełnieniem przez ankietowanego roli obserwatora w ćwiczeniach

\begin{tabular}{|c|c|c|c|c|}
\hline $\begin{array}{c}\text { Wariant } \\
\text { odpowiedzi }\end{array}$ & $\begin{array}{c}\text { JRG } \\
\text { Będzin }\end{array}$ & $\begin{array}{c}\text { JRG } \\
\text { Zawiercie }\end{array}$ & Razem & $\begin{array}{c}\text { Ujęcie } \\
\text { procentowe }\end{array}$ \\
\hline Tak & 22 & 15 & 37 & $44 \%$ \\
\hline Raczej tak & 17 & 11 & 28 & $33 \%$ \\
\hline Raczej nie & 3 & 11 & 14 & $17 \%$ \\
\hline Nie & 4 & 1 & 5 & $6 \%$ \\
\hline
\end{tabular}

Źródło: badania własne 
Pomimo że założono tylko bierny udział respondentów w ćwiczeniach kompleksowych, większość z nich dostrzega korzyści płynące $\mathrm{z}$ takiego wariantu udziału w ćwiczeniach. Zaobserwować to można po wskaźniku procentowym dla wariantu pozytywnego (odpowiedzi: „Tak” i „Raczej tak”) oraz po wskaźniku dla wariantu negatywnego w którym użyto trzy razy więcej wskazań nie do końca negatywnych (odpowiedź: „Raczej nie”).

W dziewiętnastym pytaniu respondenci wyrazili swoje zdanie na temat najbardziej interesującej i przydatnej dla nich formy ćwiczeń. Mieli możliwość wskazania jednego z czterech wariantów odpowiedzi. Wynik badania - Tabela 24. Po dokonaniu interpretacji wyników badań autor doszedł do wniosku, że zdecydowanie najbardziej interesującą i przydatną w procesie doskonalenia zawodowego strażaków PSP formą ćwiczeń jest forma praktyczna. Dość ważnym elementem, na który zwracają uwagę respondenci, jest szkolenie teoretyczne lub rodzaj odprawy szkoleniowej przed częścią praktyczną ćwiczeń. Odpowiedź tę wybrało $68 \%$ ankietowanych.

Tabela 24. Opinia ankietowanych na temat najbardziej interesującej i przydatnej dla nich formy ćwiczeń

\begin{tabular}{|l|c|c|c|c|}
\hline \multicolumn{1}{|c|}{ Wariant odpowiedzi } & $\begin{array}{c}\text { JRG } \\
\text { Będzin }\end{array}$ & $\begin{array}{c}\text { JRG } \\
\text { Zawiercie }\end{array}$ & Razem & $\begin{array}{c}\text { Ujęcie } \\
\text { procentowe }\end{array}$ \\
\hline wyłącznie aplikacyjne & 1 & 1 & 2 & $2 \%$ \\
\hline wyłącznie praktyczne & 10 & 12 & 22 & $26 \%$ \\
\hline $\begin{array}{l}\text { praktyczne połączone ze } \\
\text { szkoleniem teoretycznym / } \\
\text { odprawą szkoleniową przed } \\
\text { praktyką }\end{array}$ & 32 & 25 & 57 & $68 \%$ \\
\hline $\begin{array}{l}\text { wyłącznie szkolenie } \\
\text { teoretyczne z ewentualnym } \\
\text { aplikacyjnym sprawdzeniem }\end{array}$ & 3 & 0 & 3 & $4 \%$ \\
\hline
\end{tabular}

Źródło: badania własne

Ostatnie, dwudzieste pytanie ankiety, autor uczynił opisowym. Skierował w nim prośbę do ankietowanych o zamieszczenia własnych uwag, 
Artur Musiał - Ćwiczenia kompleksowe na lotnisku...

propozycji oraz sugestii odnoszących się do zagadnienia ćwiczeń kompleksowych i samej ankiety. Dziewięciu ankietowanych zdecydowało się na własne zapisy. Niektóre treści odpowiedzi, aby nie zwiększać objętości niniejszego artykułu, zostały zmodyfikowane stylistycznie przez autora pracy z zachowaniem ich treści merytorycznej i sensu wyrażanego przesłania. Osiem odpowiedzi odnosiło się do ćwiczeń, jedna zaś dotyczyła ankiety. Ich treść zebrano w Tabeli 25.

Tabela 25. Uwagi, propozycje, sugestie respondentów dotyczące zagadnień ćwiczeń kompleksowych, a także kierowanej do nich ankiety w ujęciu podziału na przynależność do danej JRG

\begin{tabular}{|c|c|}
\hline JRG & Treść odpowiedzi \\
\hline Będzin & $\begin{array}{l}\text { 1. wypracowanie metod organizacji wspólnych ćwiczeń } \\
\text { 2. brak szczegółowego omówienia ćwiczeń po części praktycznej } \\
\text { 3. organizacja ćwiczeń na różnych zmianach służbowych } \\
\text { 4. ankieta zrobiona profesjonalnie }\end{array}$ \\
\hline Zawiercie & $\begin{array}{l}\text { 1. sugerowany udział w ćwiczeniach tylko pobliskich jednostek } \\
\text { (2 odpowiedzi) } \\
\text { 2. ćwiczenia nie powinny być organizowane dla niektórych jed- } \\
\text { nostek } \\
\text { 3. jeśli LSR-G nie opanuje sytuacji, to zastępy PSP, które dojadą } \\
\text { z opóźnieniem, niewiele wniosą do akcji, gdyż samolot to jeden } \\
\text { wielki zbiornik paliwa } \\
\text { 4. przeprowadzanie ćwiczeń teoretycznych i praktycznych bez } \\
\text { pośpiechu i stresu („na spokojnie” - pisownia oryginalna) }\end{array}$ \\
\hline
\end{tabular}

Źródło: badania własne

Dwie odpowiedzi zdają się odnosić do zagadnienia organizacji ćwiczeń. Mianowicie: „organizacja ćwiczeń na różnych zmianach służbowych” oraz „wypracowanie metod organizacji wspólnych ćwiczeń”. Autor, bazując na wiedzy własnej i doświadczeniu zawodowym, oparł się na założeniu trzyzmianowego systemu organizacji służby w JRG PSP. Stoi to w opozycji do czterozmianowego systemu pracy LSR-G. Okoliczność ta powoduje bardzo ograniczoną możliwość przeprowadzenia ćwiczeń kompleksowych na różnych zmianach służbowych JRG 
PSP, wynikającą z dążenia dopasowania terminu ćwiczeń do kolejnej zmiany LSR-G jako służby wiodącej. Rozwiązaniem idealnym, jakie nasuwa się autorowi, może być przeprowadzanie ćwiczeń częściowych. Nie zastąpi to oczywiście wykorzystania walorów, jakie dają ćwiczenia kompleksowe, lecz przy odpowiedniej organizacji i doborze wariantów ćwiczeń, daje możliwość ćwiczenia wszystkich etapów działań ratowniczych. Priorytetem $\mathrm{w}$ tym przypadku powinno pozostać dopasowanie terminu dogodnego dla zmian służbowych JRG PSP.

Pośród uwag znalazła się i taka, która zwraca uwagę na „brak szczegółowego omówienia ćwiczeń po części praktycznej”. Autor znów odwoła się do swojej wiedzy i doświadczenia zawodowego. Odprawy organizowane w celu omówienia ćwiczeń kompleksowych są organizowane $\mathrm{z}$ racji prawnego obowiązku ich przeprowadzania. Ich uczestnikami są także przedstawiciele PSP. Autor nie czuje się upoważniony do wydania opinii na temat przepływu informacji w PSP. Propozycją autora po analizie treści tejże odpowiedzi jest organizacja spotkań ze strażakami PSP, których głównym elementem byłoby szczegółowe omówienie niedociągnięć i błędów popełnionych podczas ćwiczeń kompleksowych. Autor chciałby odnieść się także całościowo do kolejnych sugestii. Będą to „sugerowany udział w ćwiczeniach tylko pobliskich jednostek (2 odpowiedzi)” i „ćwiczenia nie powinny być organizowane dla niektórych jednostek". W połączeniu tychże sugestii $\mathrm{z}$ przeanalizowanym $\mathrm{w}$ tych przypadkach stażem zawodowym ankietowanych można dojść do wniosku, że są to opinie osób z niewielkim doświadczeniem zawodowym. Uzasadnieniem założenia autora, może być fakt nie do końca poprawnego zrozumienia potrzeby i idei przeprowadzania ćwiczeń kompleksowych, brak znajomości aktów prawnych regulujących zasady ich organizacji i zadań, jakie pełni jednostka ratowniczo-gaśnicza znajdująca się w pobliżu lotniska.

Do niemal identycznych wniosków można dojść po analizie kolejnej wypowiedzi: „jeśli LSR-G nie opanuje sytuacji, to zastępy PSP, które dojadą z opóźnieniem, niewiele wniosą do akcji, gdyż samolot to jeden wielki zbiornik paliwa". Można zgodzić się w pewnym sensie z autorem 
Artur Musiał - Ćwiczenia kompleksowe na lotnisku...

tejże wypowiedzi, lecz dostrzec w niej można brak doświadczenia zawodowego. W rzeczywistości podczas wypadku statku powietrznego na lotnisku PSP jako priorytet wykonuje działania ratownicze, lecz należy wziąć pod uwagę, iż wypadki lotnicze nie zawsze zdarzają się nieoczekiwanie. W swojej karierze zawodowej autor doświadczył kilkudziesięciu awaryjnych lądowań stanowiących przesłanki do wypadku lotniczego, o których wiadomo było z dużym wyprzedzeniem czasowym. W większości tych przypadków siły i środki PSP zdążyły zgromadzić się w rejonie koncentracji, oczekując na rozwój wydarzeń.

Na dozę uwagi zasługuje kolejna wypowiedź: „przeprowadzanie ćwiczeń teoretycznych i praktycznych („na spokojnie” - pisownia oryginalna)". W opinii autora to sygnał wysłany przez strażaków PSP do chęci udziału w szkoleniach na lotnisku. Wskazuje na to używane słownictwo: „bez pośpiechu i stresu, na spokojnie”. Ta forma wypowiedzi uwidacznia chęć nauczenia się czegoś nowego poprzez np. udział w zajęciach prowadzonych $\mathrm{w}$ formie instruktażu.

Jako szczególnie ważna dla autora przytoczona zostanie ostatnia wypowiedź: „ankieta zrobiona profesjonalnie”. Daje ona powód do dumy autorowi i pozostawia go w przeświadczeniu, że problem badawczy, jaki podjął jest ważny, a poprzez dobrze opracowane pytania w ankiecie wyniki badania będą obiektywne.

\section{Podsumowanie}

Doskonalenie zawodowe to według J. Bednarka i P. Bielickiego „pogłębianie wiedzy podporządkowane potrzebom zawodowym oraz usprawnianie nabytych umiejętności z zakresu stosunkowo wąskiego profilu kształcenia"15. Celem zaś doskonalenia zawodowego według autorów jest rozwijanie wiedzy, sprawności działania i myślenia jako

15 J. Bednarek, P. Bielicki, Podstawy psychologii pedagogiki i metodyki kształcenia pożarniczego, Warszawa 1997, s. 82. 
elementów potrzebnych do wykonywania zadań w nowych sytua$\operatorname{cjach}^{16}$.

Strażacy z jednostek wytypowanych do badania stanowią doświadczoną grupę zawodową z zauważalną, naturalną rotacją personelu.

Przeprowadzone badania wskazują, że poziom wyszkolenia strażaków PSP w zakresie ratownictwa lotniskowego kształtuje się na poziomie średnim. Czynnikiem wpływającym na ten stan rzeczy jest: brak jednolitych zasad prowadzenia szkoleń i doskonalenia zawodowego w jednostkach PSP ukierunkowanych na działania ratowniczo-gaśnicze po wypadku statku powietrznego. Strażacy PSP posiadają ogólną, teoretyczną wiedzę, którą zdobywają na kursach strażaków jednostek ochrony przeciwpożarowej, w szkołach aspirantów i w uczelni branżowej, jaką jest Szkoła Główna Służby Pożarniczej. Badania pokazały, że zasady prowadzenia działań podczas wypadku lotniczego są im znane. Brak im zaś nader ważnego elementu, jakim jest wiedza praktyczna. Strażacy PSP nie mają dostępu do wiedzy w kwestii coraz dynamiczniej ewoluujących taktyk ratowniczo-gaśniczych. Stają się one dla nich szczególnie ważne podczas interwencji poza rejonem operacyjnym lotniska, do których LSR-G nie ma obowiązku przystępować (rejon operacyjny lotniska to obszar o promieniu $8 \mathrm{~km}$ od lotniska). Rozwój technologii konstrukcji statków powietrznych, jakim dla przykładu jest zastosowanie materiałów kompozytowych, niesie większe zagrożenie dla ratowników podczas wypadku i niejednokrotnie pożaru statku powietrznego, niż w przypadku konstrukcji tradycyjnych. Determinuje to stosowanie bardziej rozbudowanych taktyk ratowniczo-gaśniczych, a niewiedza staje się wówczas śmiertelnym zagrożeniem.

Na podstawie przeprowadzonych badań można stwierdzić, że strażacy PSP odczuwają potrzebę uczestniczenia w ćwiczeniach kompleksowych na lotnisku. W ich odczuciu ćwiczenia są ważnym elementem procesu doskonalenia zawodowego, a dla niektórych z nich szkolenia. Jak wcześniej wspomniano, termin przeprowadzenia ćwiczeń kompleksowych jest dostosowywany do LSR-G. Przeszkodą do cyklicznego

16 Ibidem. 
Artur Musiał - Ćwiczenia kompleksowe na lotnisku...

systematycznego udziału w ćwiczeniach kompleksowych strażaków PSP są systemy pracy obu formacji. Stąd też za szczególnie ważne należy uznać dopracowywanie koordynacji służb ratowniczych poprzez organizowanie wspólnych szkoleń i ćwiczeń częściowych. Ich główny temat powinno stanowić ogólnie rozumiane ratownictwo lotniskowe. Elementy te przyczynią się do polepszenia efektywności procesu szkolenia lub doskonalenia zawodowego strażaków PSP w zakresie ratownictwa lotniskowego. W tym miejscu można zadać pytanie: Czy strażakom każdej Jednostki Ratowniczo-Gaśniczej PSP, nawet tej nieplanowanej do działań na lotnisku, wiedza ta jest potrzebna? Otóż paradoksalnie można stwierdzić, że tak. Jako argument należy wysunąć fakt zagęszczenia korytarzy powietrznych nad terytorium naszego kraju. Uwidacznia to rosnące prawdopodobieństwo wypadku lotniczego poza rejonem operacyjnym lotniska, gdzie PSP jest zdana na własne umiejętności.

Najbardziej pożądanym rozwiązaniem, jakie chciałby zaproponować autor, byłoby uruchomienie ośrodka doskonalenia zawodowego, który pozwoliłby na symulację różnorakich wariantów sytuacji zagrożenia mogących zdarzyć się na lotnisku. Dawałby możliwość m.in:

- dopracowywania zasad współdziałania obu formacji w strefie zagrożenia,

- zapoznawania się z nowymi taktykami działania,

- wymiany doświadczeń zawodowych, co w szerszej perspektywie miałoby przełożenie na bezpieczeństwo lotniska, a patrząc jeszcze szerzej, na bezpieczeństwo państwa.

Na przestrzeni kilkunastu lat da się dostrzec dynamiczny rozwój transportu lotniczego. Wpływ na to ma m.in. znaczący spadek cen biletów lotniczych. Samolot stał się dla społeczeństwa powszechnym i łatwo dostępnym środkiem lokomocji. Statystyki pokazują, że lotnictwo to najbezpieczniejszy środek transportu. Nie należy zapominać jednak, że na pokładzie najbardziej popularnych samolotów znajduje się średnio około 200 osób, dlatego też sprawne współdziałanie służb ratowniczych podczas działań w strefie zagrożenia staje się szczególnie ważne. 


\section{Bibliografia:}

Bednarek J. Bielicki P., Podstawy psychologii pedagogiki i metodyki kształcenia pożarniczego, Wyd. „Firex”, Warszawa 1997.

Łuczak K. (red.), Zarządzanie bezpieczeństwem w lotnictwie cywilnym, Wyd. Uniwersytetu Śląskiego w Katowicach, Katowice 2016.

Siadkowski A. K., Prawodawstwo w ochronie lotnictwa cywilnego, Wydawnictwo Naukowe Akademii WSB, Dąbrowa Górnicza 2015.

Szczucki J, Gąsior M., Zając G., Szczelina M., Zarządzanie bezpieczeństwem lotnictwa cywilnego. Skrypt dydaktyczny, Wyd. Dolnośląskiej Szkoły Wyższej, Wrocław 2011.

\section{Akty prawne:}

Konstytucja Rzeczypospolitej Polskiej z dnia 2 kwietnia 1997 r. (Dz.U. 1997, $\mathrm{Nr} 78$, poz. 483)

Ustawa z dnia 24 sierpnia 1991 r. o Państwowej Straży Pożarnej (t.j. Dz.U. 1991, Nr 88, poz. 400)

Ustawa z dnia 3 lipca 2002 r. Prawo lotnicze (t.j. Dz.U. 2002, Nr 130, poz. 1112). Konwencja o międzynarodowym lotnictwie cywilnym podpisana w Chicago dnia 7 grudnia 1944 r. (Dz.U. 1959, Nr 35, poz. 212 ze zm.)

Rozporządzenie Komisji (UE) NR 139/2014 z dnia 12 lutego 2014 r. ustanawiające wymagania oraz procedury administracyjne dotyczące lotnisk zgodnie z rozporządzeniem Parlamentu Europejskiego i Rady (WE) nr 216/2008 (Dz.U. UE L 44 z 14.02.2014 r.)

Rozporządzenie Ministra Transportu, Budownictwa i Gospodarki Morskiej z dnia 4 kwietnia 2013 r. w sprawie przygotowania lotnisk do sytuacji zagrożenia oraz lotniskowych służb ratowniczo-gaśniczych (Dz.U. 2013, poz. 487).

\section{Załączniki do Konwencji o Międzynarodowym Lotnictwie Cywilnym}

Załącznik 14, Tom I, Projektowanie i eksploatacja lotnisk, wydanie piąte, 2009 (Dz. Urz. ULC z 2011 r. Nr 4, poz. 4.) 
Artur Musiał - Ćwiczenia kompleksowe na lotnisku...

\section{Inne dokumenty:}

Statistical Summary of Commercial Jet Airplane Accidents Worldwide Operations 1959-2017, dokument elektroniczny [dostęp: 12-04-2019].

Doc 9137-AN/898 Podręcznik służb lotniskowych Część 7 Planowanie działań w sytuacjach zagrożenia w porcie lotniczym, „Wytyczne nr 11 Prezesa Urzędu Lotnictwa Cywilnego z dnia 22 września 2016 r. w sprawie wprowadzenia do stosowania wymagań ustanowionych przez Organizację Międzynarodowego Lotnictwa Cywilnego (ICAO) - Doc 9137-AN/898 Część 1 i 7" (Dz. Urz. ULC z 2016 r. poz. 76)

Łatwo dostępne przepisy dla lotnisk (Rozporządzenie (UE) nr 139/2014) wersja w języku polskim opublikowana na podstawie dokumentu EASA: Easy Acces Rules For Aerodromes (Regulation (EU) No 139/2014), EASA maj 2019, dokument elektroniczny [dostęp:12-05-2019].

\section{Netografia:}

- http://www.boeing.com

- http://www.isip.sejm.gov.pl

- http://www.rjp.pan.pl

- http://www.ulc.gov.pl 